\title{
WSPÓŁCZESNE PROBLEMY W ZAGOSPODAROWANIU LODZI W OPINII UŻYTKOWNIKÓW PRZESTRZENI MIEJSKIEJ
}

\section{CONTEMPORARY PROBLEMS IN THE DEVELOPMENT OF ŁÓDŹ IN THE OPINIONS OF URBAN SPACE USERS}

DOI: $10.25167 / \mathrm{sm} 2017.025 .04 \quad$ s. $77-91$

\begin{abstract}
ABSTRAKT: W artykule podjęto temat postrzegania problemów w zagospodarowaniu Łodzi przez osoby z niego korzystające. Analizie poddano 160 szczegółowych wypowiedzi pisemnych młodych użytkowników przestrzeni miejskiej, uzupełnionych przez autorkę danymi o charakterze obiektywnym. W opracowaniu założono zbadanie struktury rodzajowej problemów i ich przyczyn, rozmieszczenia i struktury własnościowej nieruchomości dotkniętych nieprawidłowościami, a także ukazanie propozycji rozwiązań przedstawionych problemów. Badane osoby najsilniej krytykowały zaniedbanie i dewastację tkanki miejskiej w centralnej części miasta, a także zakłócenia ładu przestrzennego w sferze wizualnej. W subiektywnej opinii „winę” za te problemy ponoszą przede wszystkim prywatni inwestorzy, ale także władze - odpowiadające za projekty inwestycji, uchwalanie prawa lokalnego i jego egzekucję. Wśród najważniejszych działań na rzecz rozwiązania sytuacji problemowych znalazły się inwestycje infrastrukturalne oraz optymalizacja prawa lokalnego i procedur administracyjnych.
\end{abstract}

SŁOWA KLUCZOWE: przestrzeń miejska, problemy w zagospodarowaniu, Łódź

ABSTRACT: In this article urban users' perception of problems in the development of Lódź is analyzed. It concerns 160 essays prepared by young people who move around the city regularly. The opinions were supplemented by the author with objective data. The paper examines the range of problems and reasons for their appearance, spatial pattern and ownership of estates affected by improprieties, and presents solutions suggested in this field. People participating in the research heavily criticized negligence and devastation of the urban tissue in the central part of the city, as well as disruptions of spatial order in its visual dimension. According to subjective opinions, the main actors responsible for those problems are private investors and the authorities who carry out investment projects, pass law and execute it. Among crucial actions suggested for solving problems in the built environment there are infrastructural investments as well as optimization of local law and administrative procedures.

KEY WORDS: urban space, problems in the built environment, Lódź

* Uniwersytet Łódzki, Wydział Nauk Geograficznych, Instytut Zagospodarowania Środowiska i Polityki Przestrzennej, Zakład Fizjografii i Planowania Przestrzennego, ul. Kopcińskiego 31, 90-142 Łódź, tel. 42635 45 78, e-mail: iwona.pielesiak@geo.uni.lodz.pl 


\section{Wprowadzenie}

Miasta stanowią środowisko mieszkaniowe, miejsce pracy i rekreacji dla olbrzymiej grupy ludności. Według danych Organizacji Narodów Zjednoczonych obszary zurbanizowane są obecnie zamieszkiwane przez 53,9\% z 7,34 mld globalnej populacji (World Urbanization... 2014). W Polsce wskaźnik ten wynosi 60,3\% („Rocznik Demograficzny" 2016). Koncentracja tak licznej zbiorowości na stosunkowo niewielkim obszarze skutkuje częstym pojawianiem się problemów w sferze przyrodniczej, społecznej i ekonomicznej. Stanowi ona tym samym wyzwanie dla gospodarki przestrzennej, której jednym z celów jest odpowiednie kształtowanie warunków bytowych oraz ulepszanie środowiska życia ludności. Ma to umożliwiać społeczeństwu funkcjonowanie w „zdrowym" i „cywilizowanym” otoczeniu (Parysek 2006).

Aby gospodarowanie przestrzenią miejską było efektywne, musi być poprzedzone diagnozą problemów, w szczególności tych, które uwidaczniają się w sferze zagospodarowania przestrzennego. Zagadnienie to stało się przedmiotem zawartej w artykule analizy. Przedstawiono je na przykładzie Łodzi - trzeciego co do liczby mieszkańców miasta w Polsce.

\section{Cel, materiały i metody}

Głównym celem artykułu jest zbadanie struktury rodzajowej problemów w zagospodarowaniu Łodzi, zauważanych przez użytkowników przestrzeni miejskiej. Jednocześnie poddano analizie rodzaj oraz rozmieszczenie miejsc, w których dostrzeżono nieprawidłowości. Dodatkowym celem było zbadanie opinii na temat przyczyn problemów wskazanych przez osoby uczestniczące w badaniu. Ostatnią poruszoną w artykule kwestią było ukazanie propozycji rozwiązań dla zidentyfikowanych nieprawidłowości.

Do badania wybrano szczególnych użytkowników przestrzeni - studentów uzupełniających studiów magisterskich kierunku gospodarka przestrzenna na Wydziale Nauk Geograficznych i Wydziale Zarządzania Uniwersytetu Łódzkiego. Były to osoby, które stosunkowo dobrze znają Łódź, często się w jej obrębie przemieszczają, a dodatkowo mają szeroką wiedzę na temat problemów zagospodarowania miast.

W latach 2014-2016 studenci zostali poproszeni o przygotowanie prac pisemnych, w których identyfikowali problemy w zagospodarowaniu wybranego obszaru. Ich zadaniem było szczegółowe przedstawienie rodzaju nieprawidłowości, jej lokalizacji i genezy, ukazanie wpływu na użytkowników przestrzeni oraz wskazanie potencjalnych sposobów rozwiązania. Ostatnim elementem pracy był wybór rozwiązania, które badani uznali za optymalne.

Spośród 247 pisemnych wypowiedzi (w tym 175 kobiet) do dalszej analizy wybrano jedynie te, które zostały w całości przygotowane według powyższych zaleceń oraz identyfikowały problem zlokalizowany w Łodzi. Do szczegółowego przeglądu zakwalifikowano 160 prac, głównie autorstwa studentek, które stanowiły aż 76,3\% ogółu bada- 
nych. Tak wyraźna dominacja kobiet w wypowiadającej się grupie sprawiła, że analiza zróżnicowania postrzegania problemów w zagospodarowaniu Łodzi w zależności od płci nie została przeprowadzona.

Spośród wszystkich prac przygotowanych w 2014 r. do szczegółowego badania wybrano 49, a w kolejnych latach odpowiednio 37 i 74. Zdecydowana większość osób, które przedstawiły swoje opinie na temat problemów w zagospodarowaniu, była w wieku od 22 do 23 lat. Około połowy przebadanej zbiorowości stanowiły osoby na stałe zameldowane $\mathrm{w}$ Łodzi, pozostałe przebywały w mieście czasowo, w związku z podjęciem studiów na Uniwersytecie Łódzkim. Z uwagi na brak adresów zamieszkania badanych osób (ze względu na ochronę danych osobowych) możliwość analizy wpływu tego czynnika na uzyskany obraz była ograniczona. Wypowiedzi badanych zostały uzupełnione przez autorkę o dane na temat własności nieruchomości, typu użytkowania ziemi we wskazanym obszarze oraz jego odległości od centrum Łodzi. Następnym etapem procedury badawczej była analiza kartograficzna oraz statystyczna. W drugim przypadku przeanalizowano rozkład częstości zmiennych oraz oceniono związek między cechami w oparciu o tabele krzyżowe. W badaniach wykorzystano także test $\chi^{2}$, jednak wymagania odnośnie jego użycia $w$ odniesieniu do liczebności teoretycznych znacząco ograniczyły jego użycie.

Do analiz wykorzystano ostatecznie następujące zmienne: rok badania; rodzaj zidentyfikowanego problemu; rodzaj miejsca/obszaru, w którym zauważono problem (ulica/skrzyżowanie, plac, osiedle mieszkaniowe itp.); przeznaczenie terenu, na którym zidentyfikowano problem (wg Atlasu miasta Łodzi 2002), odległość „problematycznego" miejsca/obszaru od skrzyżowania ul. Piotrkowskiej i al. Piłsudskiego (położonego w centrum miasta, na przecięciu głównych osi: biegnącej równoleżnikowo trasy W-Z oraz rozciągającego się południkowo reprezentacyjnego deptaka); przyczyna zaistnienia problemu; właściciel „problematycznej” nieruchomości oraz propozycja rozwiązania problemu.

\section{Postrzeganie obszarów problemowych w Łodzi}

\section{Struktura obszarów problemowych}

Zdecydowana większość badanych wskazała tylko jedną kwestię problematyczną, podczas gdy mniej niż 1/5 wypowiadających się osób zidentyfikowało kilka współistniejących zjawisk negatywnych. Do najliczniej wymienianych kwestii należały zaniedbanie, dewastacja oraz szeroko rozumiane niedoinwestowanie (rysunek 1).

Użytkownicy przestrzeni miejskiej negatywnie wypowiadali się na temat pustostanów (głównie obiektów mieszkaniowych w zabudowie czynszowej), nawierzchni ciągów pieszych, nieuporządkowania i niskiej jakości terenów zieleni, a także braku, niedostatecznej liczby i jakości mebli miejskich. Zaniedbania tego rodzaju wiązano niemal we wszystkich przypadkach z obszarem leżącym w centrum Łodzi (jednostki 


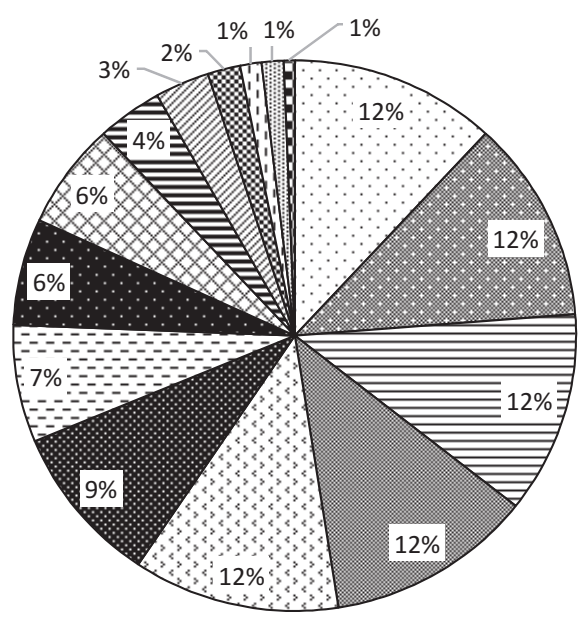

$\therefore$ Zaniedbanie, dewastacja

\% Chaos w zabudowie

Eolizyjne sąsiedztwo funkcji

ॠ Złe funkcjonowanie zagospodarowania

Pozostałe złożone

Ubytki w zabudowie

E-- Brak miejsc parkingowych

$\because$ Niedoinwestowanie

凤 Złożone (związane z niedoinwestowaniem)

車 Zbędne inwestycje

$\mathbb{\nVdash}$ Złożone (związane z chaosem w zabudowie i reklamowym)

8 Grodzenie terenu

i. Nielegalne wyburzenie obiektów

Chaos reklamowy

Brak zieleni

Rys. 1. Problemy w zagospodarowaniu Łodzi wskazane przez badanych użytkowników przestrzeni miejskiej Źródło: Opracowanie własne na podstawie pisemnych wypowiedzi osób uczestniczących w badaniu.

pomocnicze Katedralna, Śródmieście Wschód, a w mniejszym stopniu Stare Polesie i Stary Widzew). Niedoinwestowanie przypisywano głównie przestrzeniom publicznym, problemy z parkowaniem - osiedlom mieszkaniowym, złe funkcjonowanie zagospodarowania - ulicom i skrzyżowaniom dróg, zaś ubytki i pozostałe przejawy chaosu w zabudowie - indywidualnym parcelom i obiektom usługowym.

Zaniedbanie i niedoinwestowanie piętnowano najczęściej w odniesieniu do Rynku Staromiejskiego, który od wielu lat jest postrzegany jako zapomniana przestrzeń tranzytowa, przestrzeń „w kryzysie”, która zaprzestała pełnienia istotnej roli w życiu miasta (Wycichowska 2012, Wójcik, Tobiasz-Lis 2014). Dzieje się tak mimo, iż Rynek jest jednym z kluczowych obszarów dla historii miasta. Jego zagospodarowanie oraz związane z nim funkcje niewiele się jednak zmieniły od lat 50. XX w. Współcześnie mimo sukcesywnie prowadzonych działań rewitalizacyjnych w centralnej części Łodzi obszar nie był traktowany priorytetowo. Zainteresowanie użytkowników przestrzeni miejskiej Rynkiem wzrasta jedynie okresowo, w związku z organizacją w jego obrębie różnego typu wydarzeń kulturalnych - wernisaży, instalacji artystycznych, koncertów itp.

Wywołany fizyczną degradacją, niewielką atrakcyjnością i funkcjonalnością zagospodarowania, niedorozwojem usług i niedostatkiem wydarzeń kulturalnych brak zainteresowania użytkowników Rynkiem Staromiejskim jest wiązany także z funkcjonowaniem od 10 lat leżącego w pobliżu centrum handlowo-rozrywkowego Manufaktura. Obiekt ten przyciąga mieszkańców i przyjezdnych nie tylko bogatą ofertą usługową, ale także otwartą przestrzenią, urządzoną na podobieństwo miejskiego rynku, w której często są organizowane imprezy masowe.

Kolejnym zagadnieniem, na które badane osoby zwróciły większą uwagę, był chaos w zabudowie miejskiej. Piętnowano zwłaszcza zróżnicowanie kubatury i form archi- 
tektonicznych sąsiadujących budynków (np. budynek BRE Banku na Placu Wolności, elewacja frontowa budynku Filharmonii Łódzkiej). Wrażenie „bałaganu” w zagospodarowaniu było także wywołane licznymi ubytkami w zabudowie pierzejowej oraz zaburzeniem linii zabudowy w śródmieściu. Do najczęściej wskazywanych obszarów problemowych w tym zakresie należały tereny wzdłuż al. Piłsudskiego oraz ulic Narutowicza i Zachodniej/Kościuszki, w przypadku których wyburzenie frontowych budynków na potrzeby poszerzenia ciągów komunikacyjnych poskutkowało otwarciami widokowymi na mało atrakcyjne obiekty wewnątrz parcel. Warto podkreślić, iż równie liczna grupa badanych uznała luki w zabudowie za problem odrębny, bez wiązania go z szerszym zagadnieniem, jakim jest chaos w zagospodarowaniu. Podkreślano w tym wypadku nie tylko ich negatywny wpływ na percepcję krajobrazu miejskiego, ale także utracone korzyści społeczne i ekonomiczne wynikające z istnienia niezagospodarowanych terenów pośród gęstej zabudowy śródmiejskiej.

Jeżeli chodzi o postrzeganie problemów w zagospodarowaniu w ujęciu czasowym, w kolejnych latach zauważono wzrost liczby wskazań na nieodpowiednie funkcjonowanie elementów zagospodarowania (głównie problemy komunikacyjne, nieefektywne użytkowanie nieruchomości oraz opustoszałe przestrzenie publiczne) oraz zaburzeń estetyki krajobrazu (zaśmiecenie przestrzeni publicznej reklamami). O ile pierwsza z wymienionych opinii ma poparcie w realnym wzroście obciążenia ruchem kołowym (Kowalska 2011, Wyniki Generalnego... 2015) czy szerszych badaniach nad użytkowaniem przestrzeni publicznych (Atrakcyjne przestrzenie... 2013, Pielesiak 2016), o tyle wzrastającą percepcję chaosu reklamowego można przypisać zarówno nasileniu się tego zjawiska w wymiarze obiektywnym, jak i rosnącej świadomości społecznej w tym temacie.

Choć w badanym okresie wskazania na zakłócenia ładu przestrzennego należały do najliczniej reprezentowanych kategorii, z każdym kolejnym rokiem zarówno ich liczba, jak i udział w ogóle wskazań się zmniejszały. Trudno jest jednak odpowiedzieć na pytanie, na ile wpływ na to mają sukcesywnie prowadzone przez władze lokalne i podmioty prywatne działania inwestycyjne. Podobna prawidłowość, choć w znacznie mniejszej skali, dotyczy nieuprawnionych wyburzeń obiektów budowlanych o dużej wartości historycznej i/lub architektonicznej. Wydaje się, iż pewne znaczenie przyczynowe mogło mieć usprawnienie narzędzi ochrony krajobrazu kulturowego (poprawka wprowadzona do Ustawy [...] o ochronie zabytków... w 2010 r. - por. Pielesiak 2015).

Nieruchomości/obszary wskazane przez badane osoby są w większości przypadków własnością prywatną, ponad 1/4 należy do gminy Łódź, a blisko 1/5 - do innych podmiotów publicznych. Najmniejszy udział zaobserwowano w przypadku terenów o własności mieszanej (publicznej i prywatnej).

Biorąc pod uwagę przeznaczenie gruntów, ponad połowę analizowanego zbioru stanowią obszary wielofunkcyjne. Stosunkowo duża część z nich (1/5 wskazań) to tereny mieszkaniowe, podczas gdy pozostałe kategorie - obszary przeznaczone pod usługi, działalność przemysłową, infrastrukturę techniczną, zieleń, dla rolnictwa oraz typy mieszane, mają dość wyrównany udział, nieprzekraczający 7\%. 
Analizując zmienność wskazań ze względu na rok, w którym przeprowadzono badanie, zauważono, iż z biegiem lat subiektywnie postrzegane problemy w zagospodarowaniu w coraz większym stopniu dotyczą obszarów przeznaczonych pod działalność usługową, infrastrukturę techniczną oraz terenów zieleni. Odwrotną zależność zaobserwowano w odniesieniu do terenów rolnych.

Większość osób uczestniczących w badaniu za problematyczne uznała tereny niewielkie - przede wszystkim zajęte przez obiekty usługowe (16,3\%), skrzyżowania i fragmenty ulic oraz niezabudowane działki (obie te kategorie po 15,6\%). Tylko w kilkunastu przypadkach problemy zostały przypisane obszarom dużym, kilkudziesięcio- do kilkusethektarowym terenom zieleni i gruntom rolnym, ale także osiedlom mieszkaniowym lub ich fragmentom.

\section{Rozmieszczenie obszarów problemowych}

Ponad $80 \%$ zidentyfikowanych przez badane osoby miejsc problemowych skupia się w centralnej części miasta (rysunek 2).

Więcej niż połowa obserwacji dotyczyła strefy położonej w odległości od 1 do 3 km od skrzyżowania ul. Piotrkowskiej i al. Piłsudskiego (głównie na północ od niego, w pomocniczej jednostce osiedlowej Katedralna). Uzyskany obraz silnie koresponduje z delimitacją obszarów problemowych, zawartą w Studium uwarunkowań i kierunków zagospodarowania przestrzennego Łodzi (2010). Przedstawiony zasięg odpowiada terenowi wyznaczonemu przez linię kolei obwodowej, tj. terytorium Łodzi sprzed wybuchu drugiej wojny światowej. Cechuje się ono najstarszym zainwestowaniem, największą gęstością zabudowy oraz koncentracją ludności (Atlas miasta... 2002). Z kolei większe obszary problemowe są w całości położone poza centrum, głównie w północnej części miasta. Szczególną uwagę zwrócono na Las Łagiewnicki i jego otoczenie, w przypadku których krytyce poddano efekty presji urbanizacyjnej na tereny cenne przyrodniczo (zabudowa i grodzenie terenów), a także osiedle Nowosolna, na którym za dyskusyjne uznano trasowanie planowanej obwodnicy drogowej.

Biorąc pod uwagę wypowiedzi według roku badania, wyraźny kierunek zmian w postrzeganiu lokalizacji miejsc obciążonych problemami w zagospodarowaniu dotyczy tylko jednej kategorii. Zauważono wzrost - zarówno wartości bezwzględnych, jak i udziału wskazań - w strefie położonej w odległości od 4 do $5 \mathrm{~km}$ od przyjętego punktu centralnego. Obejmuje ona głównie osiedla mieszkaniowe z okresu powojennego, w obrębie których szczególnie uciążliwe okazały się problemy komunikacyjne.

\section{Geneza problemów w zagospodarowaniu}

W opinii badanych użytkowników przestrzeni miejskiej ponad połowa przyczyn problemów w zagospodarowaniu Łodzi wynika z działań inwestorów z sektora prywatnego oraz złego projektowania (rysunek 3). Dość duży udział miały również opinie krytykujące wprost działania władz - albo niedostateczne zapobieganie wystąpieniu 


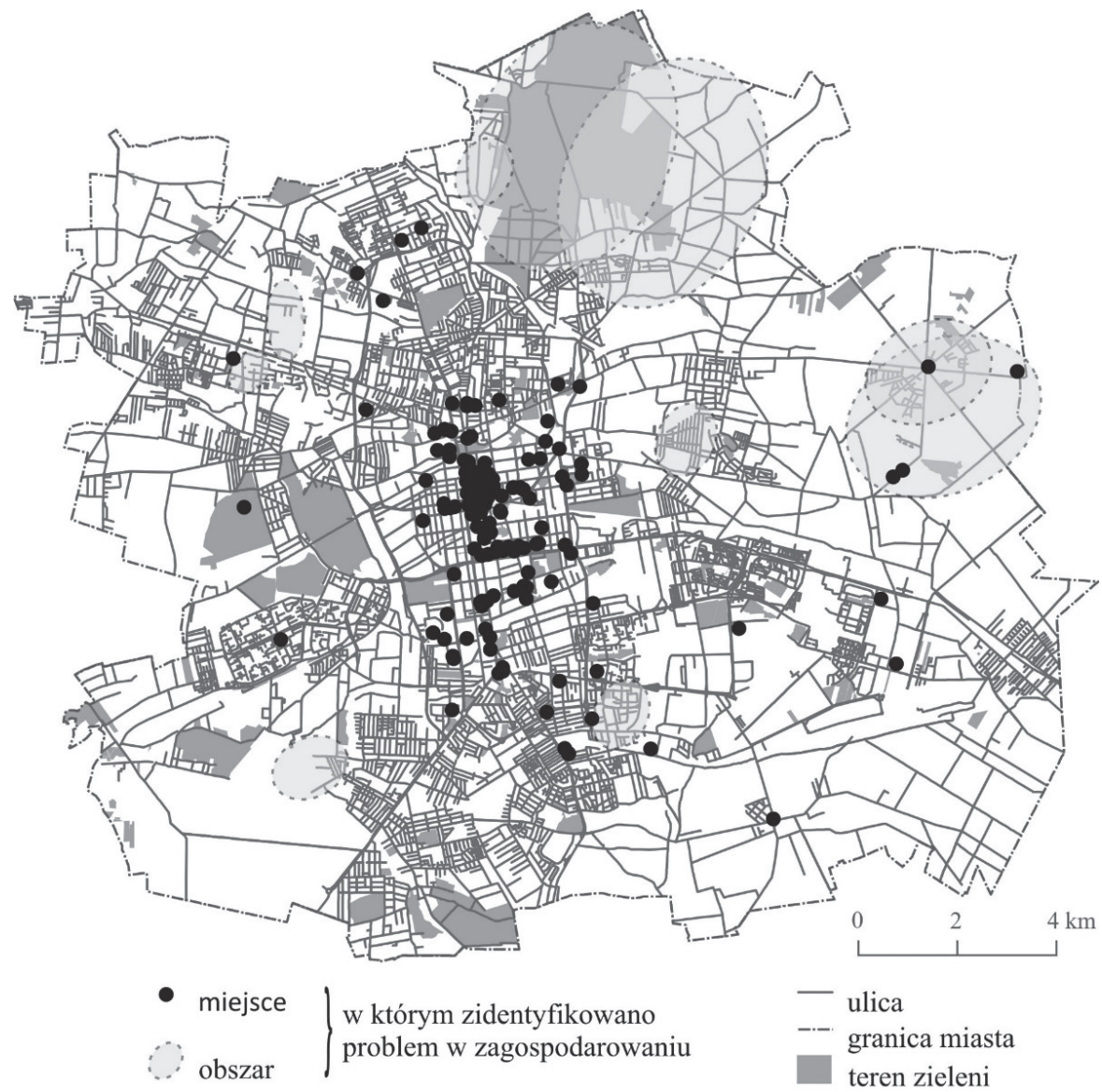

Rys. 2. Rozmieszczenie miejsc oraz obszarów uznanych za dotknięte problemami w zagospodarowaniu

Źródło: Opracowanie własne na podstawie pisemnych wypowiedzi osób uczestniczących w badaniu oraz Atlasu miasta Łodzi 2002.

problemów, albo też brak lub nieefektywną reakcję na ich wystąpienie. Podobny wydźwięk mają poglądy, iż szereg nieprawidłowości jest spowodowanych brakiem miejscowych planów zagospodarowania przestrzennego (mpzp), za które przecież także są odpowiedzialne lokalne władze samorządowe.

Zdecydowana większość badanych postrzega genezę problemów w zagospodarowaniu miasta w sposób mało skomplikowany - jako wynik oddziaływania jednego czynnika. Tylko 1/4 badanych zdaje sobie sprawę z istnienia splotu różnych okoliczności, które prowadzą do nieprawidłowości w omawianej dziedzinie.

Choć poszczególne problemy cechują się pewną rozbieżnością opinii na temat ich przyczyn, w przeanalizowanych wypowiedziach można zauważyć następujące prawidłowości: 


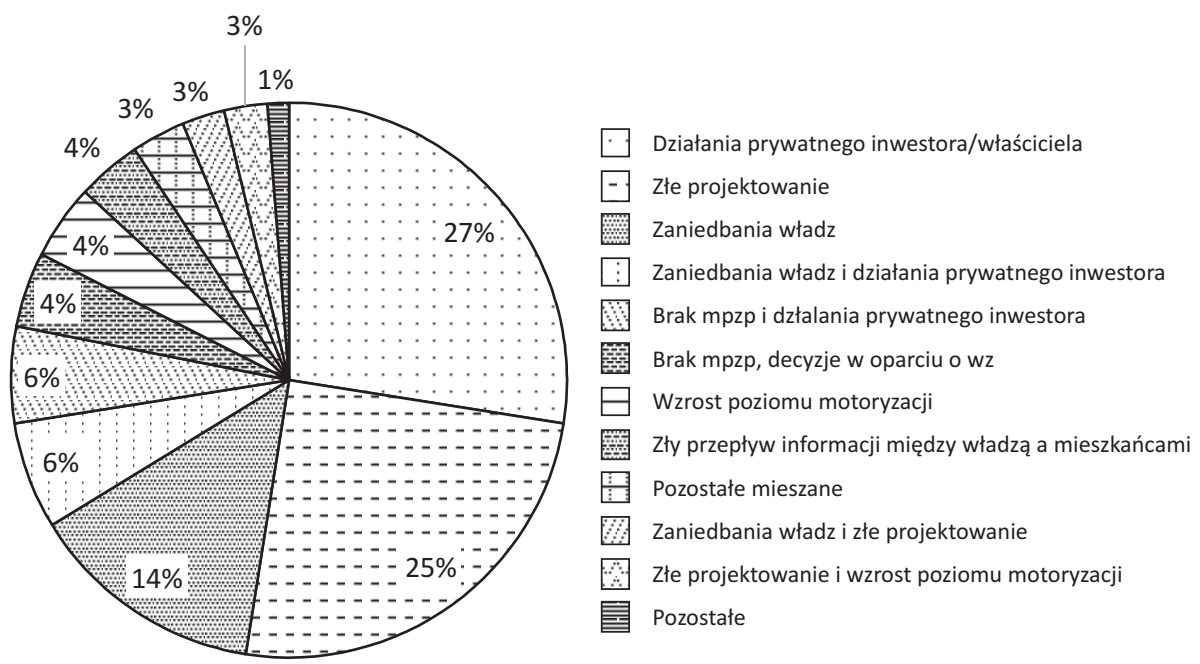

Rys. 3. Przyczyny problemów w zagospodarowaniu Łodzi w opinii badanych użytkowników przestrzeni miejskiej

Źródło: Jak w rysunku 1.

- zaniedbanie i dewastacja obiektów budowlanych w większości przypadków (47,4\% odpowiedzi w tej kategorii) zostały przypisane działaniom prywatnych inwestorów (właścicieli bądź użytkowników);

- chaos w zabudowie jest wiązany w równym stopniu (po 20\%) z ułomnościami procedur administracyjnych, zaniedbaniami władz, złym projektowaniem i działaniem prywatnych inwestorów; podobny rozkład opinii dotyczył przyczyn kolizyjnego sąsiedztwa funkcji, jednak w tym przypadku „winą" obarczano w większym stopniu czynniki instytucjonalne, głównie projektowanie i komunikację między władzą a mieszkańcami;

- rozbiórki obiektów prowadzące do powstawania ubytków w zabudowie są przypisywane przede wszystkim działalności prywatnych inwestorów (40\%);

- problemy z parkowaniem są tłumaczone głównie rosnącym poziomem motoryzacji, a w nieco mniejszym stopniu - brakiem perspektywicznego projektowania (łącznie dla obu kategorii 81,8\%);

- złe funkcjonowanie zagospodarowania przypisano nieodpowiedniemu projektowaniu (63,2\% odpowiedzi w tej kategorii).

Dwie zależności dostrzec można także, analizując wyjaśnienia problemów w kontekście lokalizacji miejsc poddanych krytyce. Mimo dość zróżnicowanego obrazu negatywne oddziaływanie prywatnych podmiotów jest wyraźniej wiązane z obszarem wielorodzinnej zabudowy o największej intensywności - do $3 \mathrm{~km}$ od przyjętego punktu centralnego Łodzi, ale także, w mniejszym stopniu, ze strefą peryferyjną miasta, dla której typowa jest zabudowa jednorodzinna. Poza tym z opinii badanych wynika, że w pierścieniu zlokalizowanym od 1 do $3 \mathrm{~km}$ od skrzyżowania ul. Piotrkowskiej i al. Pił- 
sudskiego kluczowym czynnikiem wywołującym problemy w zagospodarowaniu jest nieodpowiednie projektowanie. Według Szymona Marcińczaka (Atlas miasta... 2002) strefa ta obejmuje głównie obszary o niskim statusie społecznym, z dominacją zabudowy czynszowej.

\section{Propozycje rozwiązań problemów w zagospodarowaniu}

W odróżnieniu od wypowiedzi przeanalizowanych powyżej, tym razem ponad połowa badanych zwróciła uwagę na fakt, że nie można ograniczyć się do prostych rozwiązań zidentyfikowanych problemów (rysunek 4). Podkreślając potrzebę działań wieloaspektowych, najczęściej łączono kwestie inwestycji infrastrukturalnych, nowej aranżacji zieleni i mebli miejskich, a także konieczności uzupełnienia braków w aktach prawa lokalnego oraz ulepszenia procedur administracyjnych związanych z wydawaniem decyzji o warunkach zabudowy czy lokalizacji inwestycji celu publicznego.
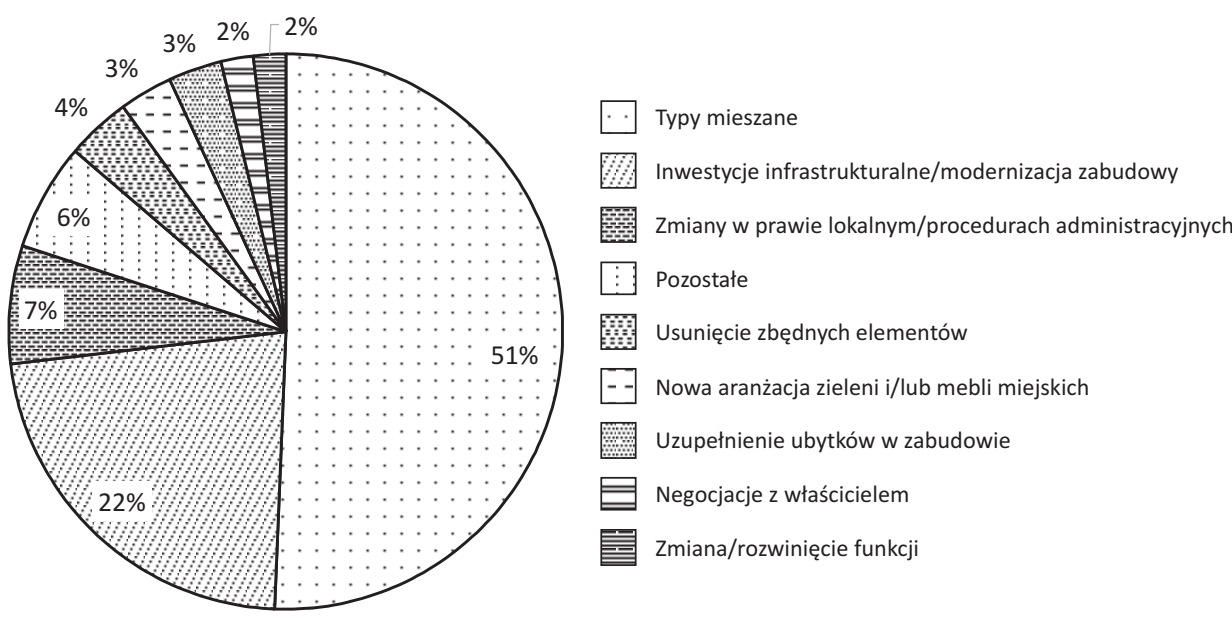

Rys. 4. Rozwiązania problemów w zagospodarowaniu Łodzi w opinii badanych użytkowników przestrzeni miejskiej - ujęcie ogólne

Źródło: Jak w rysunku 1.

Prowadząc rozważania na temat problemów w zagospodarowaniu miasta, warto zwrócić uwagę na szczegółowe propozycje rozwiązań zaproponowane przez badane osoby. Najbardziej rozwinięty ich wachlarz dotyczy zakłóceń ładu przestrzennego w odniesieniu do zabudowy i reklam zewnętrznych. Dużo uwagi poświęcono także problemom opustoszałych przestrzeni publicznych, ekstensywnego użytkowania gruntów i degradacji zabudowy w strefie wielkomiejskiej, problemów w ruchu drogowym, kolizyjnego sąsiedztwa funkcji, a także niepotrzebnych wyburzeń oraz nadmiernej presji urbanizacyjnej (tabela 1 ). 


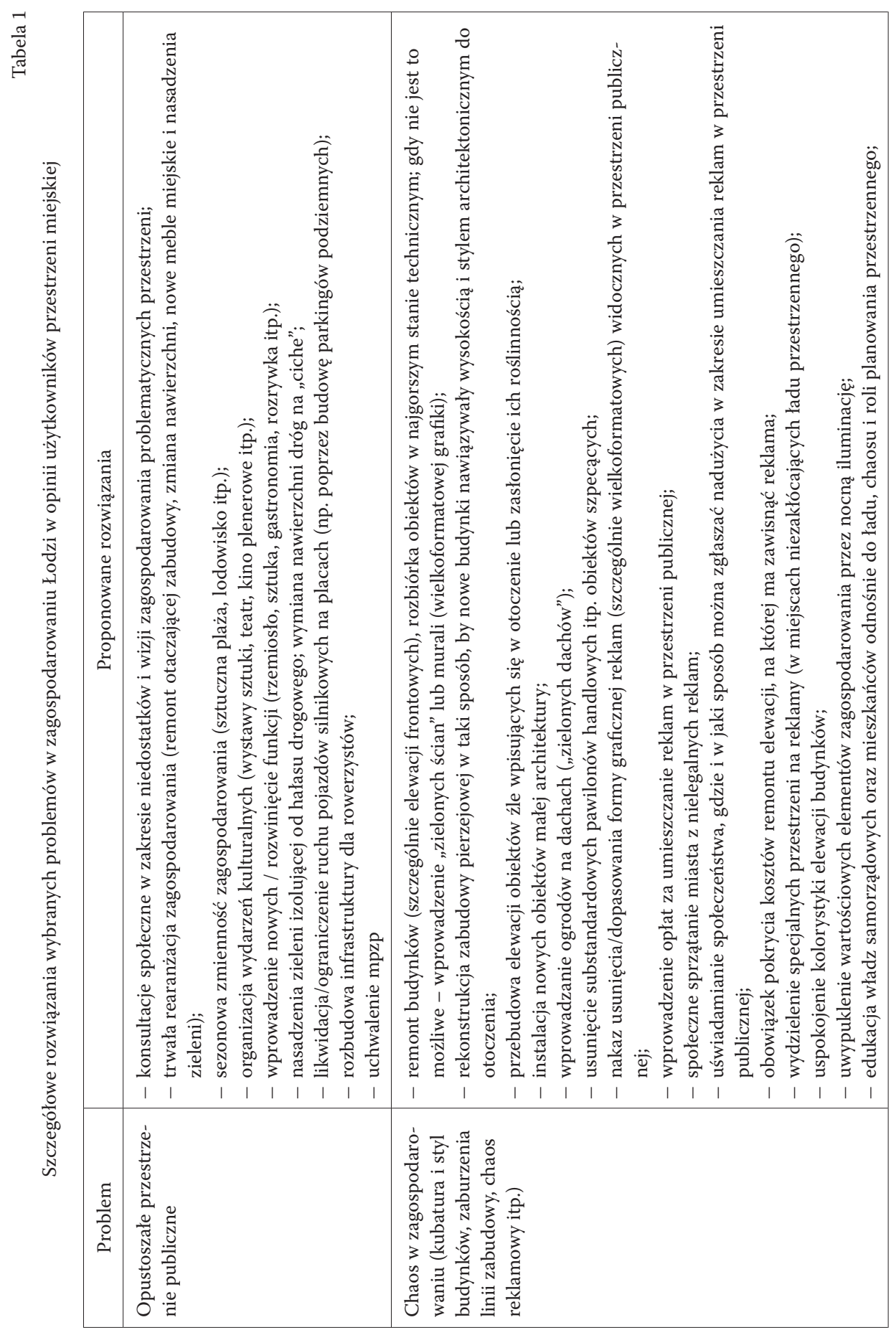


$\frac{\text { ปुं }}{\frac{\pi}{8}}$

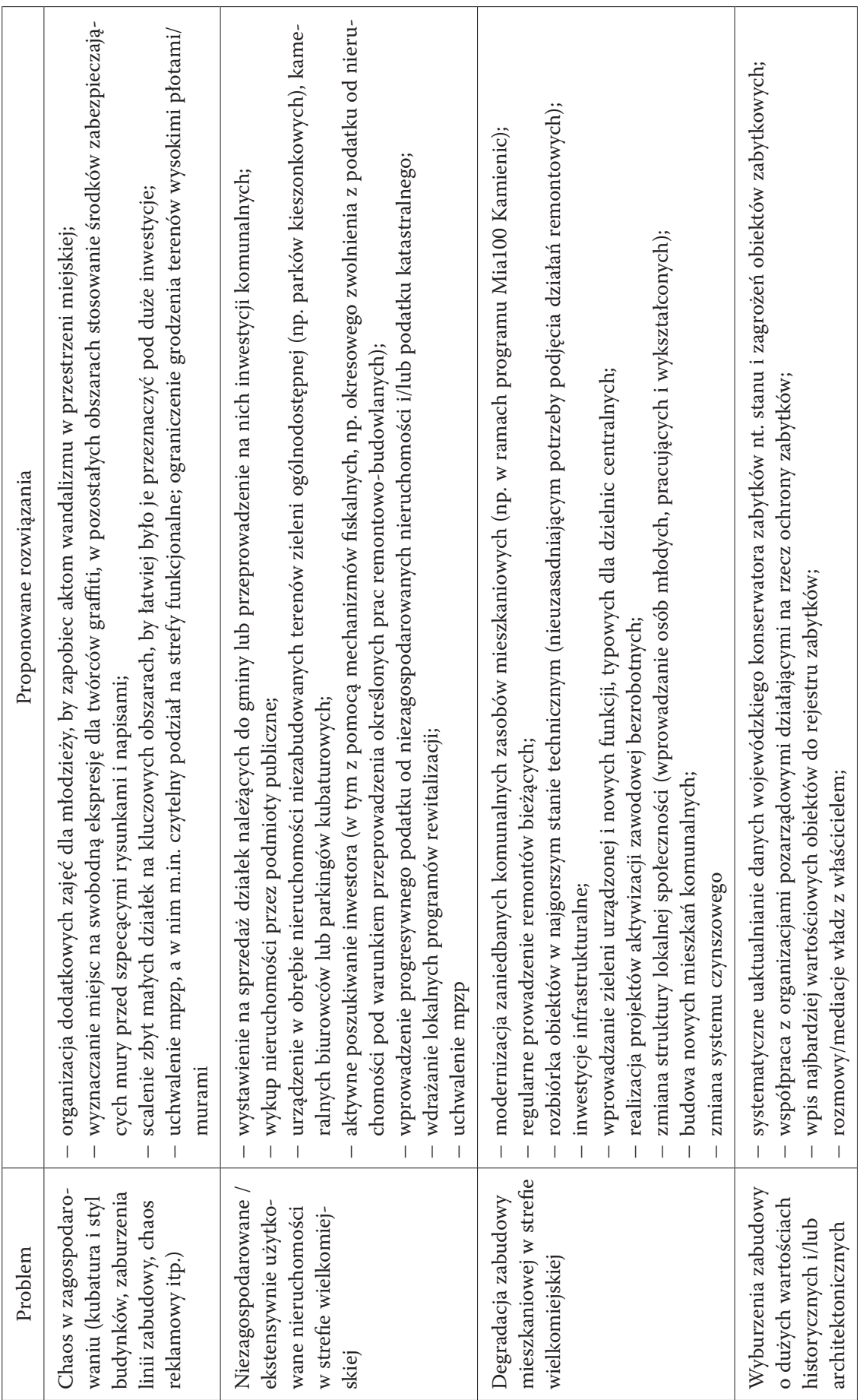




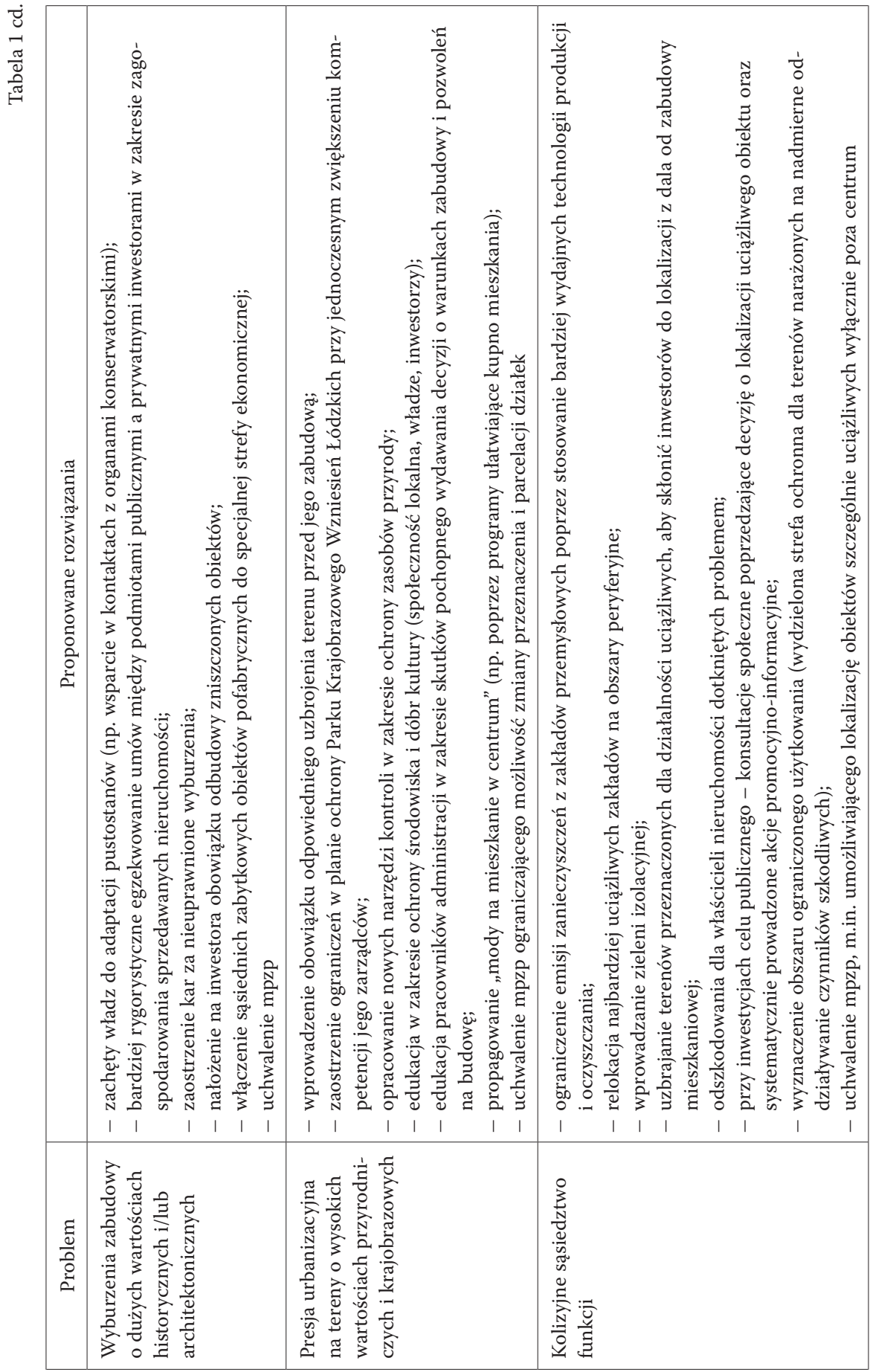




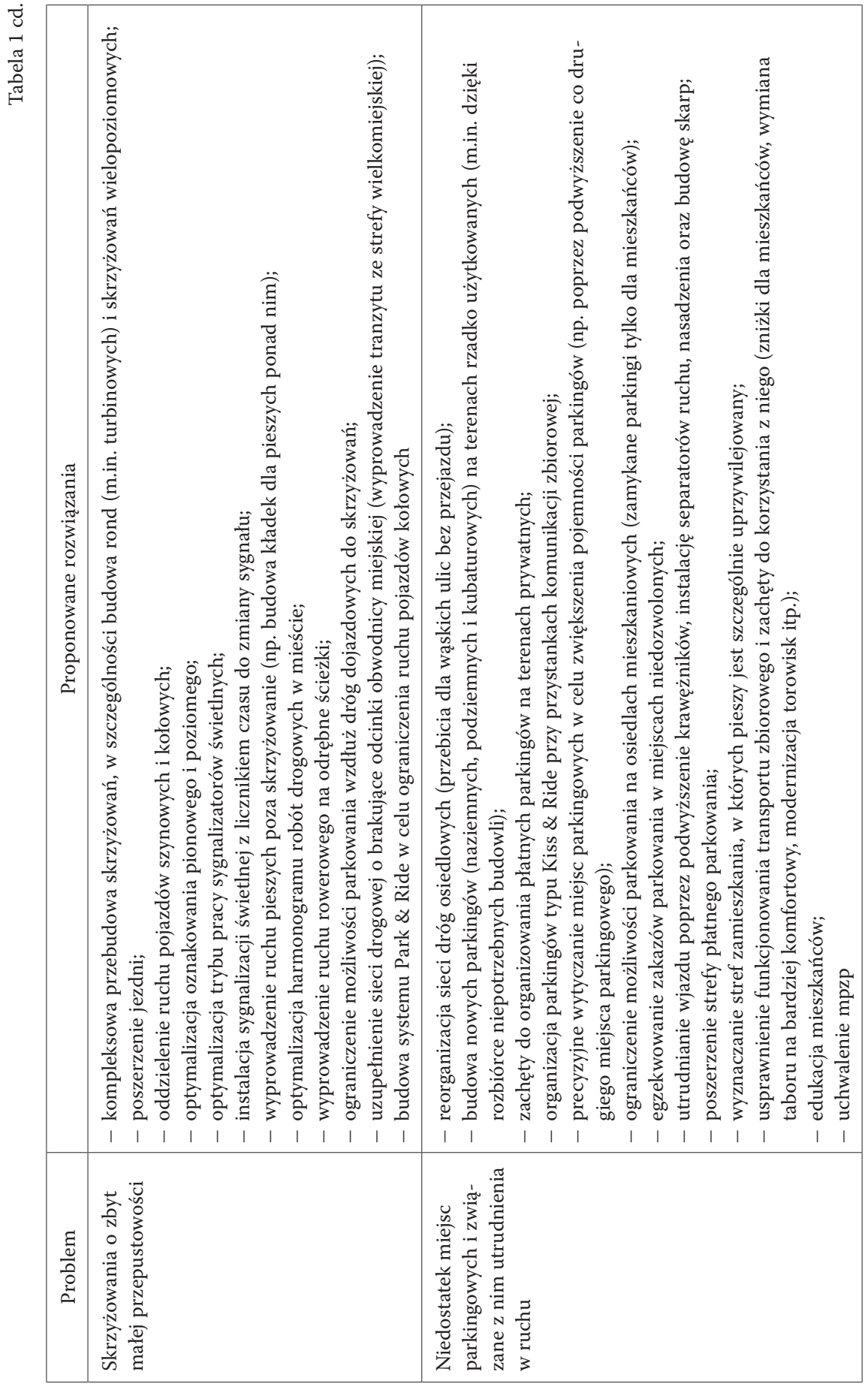

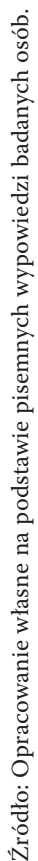


W przypadku niemal każdego rodzaju problemu wskazano na konieczność uchwalania miejscowych planów zagospodarowania przestrzennego, w których, zdaniem badanych osób, władze powinny uwzględnić bardzo precyzyjne zapisy odnośnie do obowiązującej linii zabudowy, kubatury i formy architektonicznej budynków, formy i rozmiarów ogrodzeń nieruchomości itp. W pracach dotyczących chaosu przestrzennego wielokrotnie wskazywano na konieczność uchwalenia przepisów regulujących kwestię umieszczania reklam w przestrzeni publicznej. Już w 2014 r. proponowano przy tym rozwiązania, które dopiero w 2015 r. zostały przyjęte przez ustawodawcę w tzw. ustawie krajobrazowej (Ustawa [...] o zmianie... 2015).

Część badanych osób zauważyła, iż wdrożenie proponowanych przez nie rozwiązań jednego problemu mogłoby równocześnie pozytywnie wpłynąć także na inne aspekty życia w mieście. Przykładem są wypowiedzi na temat możliwości ograniczenia zapotrzebowania na miejsca parkingowe. Poprzez różnego rodzaju zachęty do porzucania indywidualnych środków transportu na rzecz komunikacji zbiorowej pojawiłaby się dodatkowa korzyść w postaci redukcji zanieczyszczeń powietrza i hałasu.

Proponując rozwiązania, w wielu przypadkach badane osoby wskazywały na potencjalne trudności związane z prywatną własnością problematycznych nieruchomości. Poza niedostatkiem środków na sfinansowanie niezbędnych prac naprawczych ten właśnie czynnik wskazywano jako jeden z głównych hamulców pożądanych zmian w zagospodarowaniu. Dostrzeżono jednocześnie, że jednym ze środków na rozwiązanie tego problemu, choć w perspektywie długoterminowej, jest edukacja społeczeństwa na temat podmiotów, roli, zakresu i narzędzi kształtowania zagospodarowania miast. Potrzebę kształcenia użytkowników przestrzeni miejskiej podnoszono także w odniesieniu do nadmiernego uzależnienia ludności od indywidualnych środków transportu.

\section{Wnioski}

W świadomości przebadanej grupy użytkowników przestrzeni miejskiej współczesna Łódź boryka się przede wszystkim z szeroko rozumianym zaniedbaniem tkanki miejskiej i chaotycznym zagospodarowaniem, które nie tylko negatywnie wpływają na estetykę miasta, ale także ograniczają efektywność jego funkcjonowania (konfliktowe lub ekstensywne użytkowanie ziemi, coraz większe utrudnienia w ruchu drogowym itp.). Takie postrzeganie, zwłaszcza w grupie osób będących u progu podjęcia decyzji o dalszym miejscu zamieszkania, nie może być dobrą wiadomością dla lokalnych władz, próbujących przeciwdziałać pogłębiającej się depopulacji.

Natężenie zidentyfikowanych problemów ma związek z intensywnością zagospodarowania, ale także z wiekiem zabudowy. Dotknięte są nimi przede wszystkim: gęsto zabudowane śródmieście $\mathrm{z}$ dużym udziałem obiektów substandardowych oraz otaczające je osiedla zabudowy wielorodzinnej, wzniesione w pierwszych dekadach po drugiej wojnie światowej. Obszar ten od dawna pozostaje w centrum zainteresowania 
władz miejskich, jednak cechuje się on tak dużym nawarstwieniem różnego rodzaju problemów, iż nie można się spodziewać szybkiego ich rozwiązania.

Na zakończenie warto zwrócić uwagę na fakt, iż do głównych przyczyn zidentyfikowanych problemów badani zaliczyli kwestie instytucjonalne, przede wszystkim zaniedbania władz miasta w sferze planowania przestrzennego, inwestycji samorządowych i egzekucji przepisów prawa. Nie wszystkie opisane w artykule problemy mogły być jednakże spowodowane tymi czynnikami. Jeżeli tak faktycznie jest, lokalne władze powinny krytycznie przyjrzeć się swojej polityce informacyjnej, zwłaszcza w odniesieniu do przyczyn problemów w zagospodarowaniu miasta oraz możliwości swojego oddziaływania w tym zakresie.

\section{Bibliografia}

Atlas miasta Łodzi, 2002, http://www.mapa.lodz.pl/index.php?strona=atlas (dostęp 13 listopada 2016).

Atrakcyjne przestrzenie miejskie 2020+, 2013, http://bip.uml.lodz.pl/_plik.php?id=35133 (dostęp 6 lutego 2015).

Kowalska J., 2011, Analiza wyników pomiaru ruchu w 2010 r. w województwie łódzkim, Biuro Planowania Przestrzennego Województwa Łódzkiego, http://www.bppwl.lodzkie.pl /categories/3671 (dostęp 20 listopada 2016).

Prace wykonane przez studentów I roku uzupetniających studiów magisterskich kierunku Gospodarka przestrzenna w latach 2014-2016, Wydział Nauk Geograficznych. Uniwersytet Łódzki, Łódź.

Parysek J.J., 2006, Wprowadzenie do gospodarki przestrzennej, Wydawnictwo Naukowe UAM, Poznań.

Pielesiak I., 2015, Managing 'ordinary heritage' in Poland: Lódź and its post-industrial legacy, "European Spatial Research and Policy" 2015, vol. 22, No. 2.

Pielesiak I., 2016, Public spaces and social integration - the case of Lodz, [w:] The socio-spatial dimension of quality of life in the city, eds. M. Mularska-Kucharek, K. Brzeziński, Polish Academy of Sciences. Committee for Spatial Economy and Regional Planning, Warsaw. Studia Regionalia KPZK vol. 45.

„Rocznik Demograficzny” 2016, Główny Urząd Statystyczny, Warszawa.

Studium uwarunkowań i kierunków zagospodarowania przestrzennego Łodzi, 2010, uchwała nr XCIX/ 1826/10 Rady Miejskiej w Łodzi z dnia 27 października 2010 r., http://www1.mpu.lodz.pl/page/index. php?str=277 (dostęp 24 listopada 2016).

Ustawa z dnia 23 lipca 2003 r. o ochronie zabytków i opiece nad zabytkami, t.j.: Dz.U. z 2003 r., nr 162, poz. 1568.

Ustawa z dnia 24 kwietnia 2015 r. o zmianie niektórych ustaw w związku ze wzmocnieniem narzędzi ochrony krajobrazu, t.j.: Dz.U. z 2015 r., nr 1688, poz. 774.

Wyniki Generalnego Pomiaru Ruchu przeprowadzonego w 2015 r., 2015, https://www.gddkia.gov.pl/pl/2551/ GPR-2015 (dostęp 20 listopada 2016).

World Urbanization Prospects. The 2014 revision. Highlights, 2014, United Nations, New York, https://esa. un.org/unpd/wup/Publications/Files/WUP2014-Highlights.pdf (dostęp 07 listopada 2016).

Wójcik M., Tobiasz-Lis P., 2014, Ocena przestrzennych dysproporcji w Łodzi z perspektywy mieszkańców miasta, [w:] Dysproporcje społeczne i gospodarcze w Łodzi. Czynniki, mechanizmy, skutki, red. A. Suliborski, M. Wójcik, Wydawnictwo Uniwersytetu Łódzkiego, Łódź.

Wycichowska B., 2012, Zagrożona przyszłość miasta. Przykład Łodzi, „Czasopismo Techniczne. Architektura" 1-A, 1(109). 